Dr. sc. Ramiza SMAJIĆ

Institut za historiju Univerzitet u Sarajevu

E-mail: ramizas@hotmail.com

Stručni rad/Professional article

UDK/UDC: 94(497.6 Sarajevo)(091)"1995" Ancel G. (049.3)

\title{
„Bilo bi bolje da nismo uopće došli i da nismo ništa učinili“6 Guillaume Ancel, VENT GLACIAL SUR SARAJEVO, (Memoires de Guerre), Les Belles Lettres, Paris 2017, 224 str.
}

Knjiga koju je sam autor Guillaume Ancel okarakterisao kao svjedočanstvo zasnovano na teškoj vježbi pamćenja, dnevnik aktivnosti i intervjua vezanih za Sarajevo u posljednjoj godini opsade grada 1992-95, tek će se pojaviti na

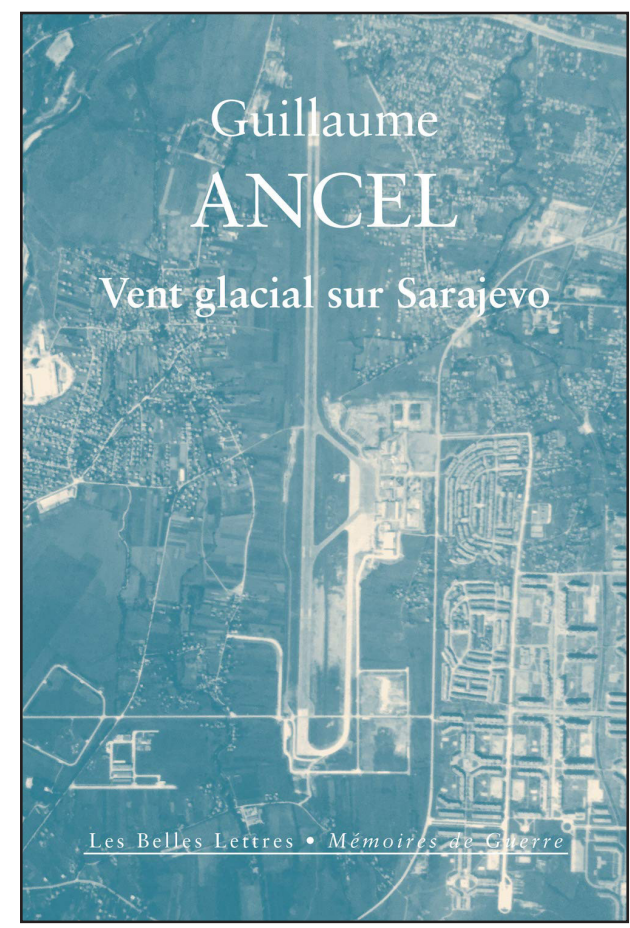
bosanskom jeziku. Ledeno nebo nad Sarajevom (Sjećanja iz rata) izdala je kuća Les Belles Lettres 2017. godine na francuskom. Već tokom 2018. godine Ancel je u nekoliko intervjua balkanskim medijskim kućama govorio o svom dolasku u Sarajevu kao visokog oficira na čelu TACP-a (Taktička oblast zračne kontrole za suzbijanje zračnih napada) za zapadni dio grada pod kontrolom Prve strane regimente. Stacioniran na Aerodromu u Sarajevu u periodu januar-juli 1995. godine, tim na čijem je čelu bio Guillaume Ancel je trebalo da u misiji Zaštitnih snaga Organizacije Ujedinjenih nacija (UNPROFOR) intervenira između zaraćenih strana radi zaštite Sarajeva i njegovog stanovništva. Prvih mjeseci je tim bio fokusiran na pronalaženje teškog naoružanja kojim se granatira opsjednuti grad. Naredni koraci u sprečavanju i uništavanju tog oružja oficiru koji je u Bosnu došao sa svježim iskustvom misija iz Kambodže i Ruande, izmijenit će potpuno njegovu percepciju francuske politike u ratu u Bosni i Hercegovini, kao i karaktera cijele misije.

Ancel dolazi u Sarajevo kad je grad već tri i po godine pod opsadom srpskih snaga i kad su aerodrom i tunel ispod piste jedina donekle otvorena veza Sarajeva sa vanjskim svijetom. Ujedinjene Nacije su u to vrijeme imale sporazum 
da ne smije biti teške artiljerije oko Sarajeva radi čega su i organizirana sabirališta tog naoružanja i municije uz legionarske punktove koji su trebali to nadzirati. Ancel se već u prvim obilascima tih lokacija suočava sa činjenicom da Srbi neometano dolaze do svog naoružanja i svakodnevno granatiraju grad sa samog sabirališta koje je pod nadzorom UN-a. Nimalo naivan prizor u kojem Srbi primjećuju na njegovim činovima polumjesec i zvijezdu kao znak Afričke regimente francuske vojske, te potežu oružje misleći da se radi o UNPROFORovim mudžahedinskim saradnicima, autor opisuje sa naznakom blagog humora, ali sa krajnjim iznenađenjem slušajući od Šefa punkta o nemoći legionara da urade išta na sprečavanju korištenja topova od strane tih srpskih snaga.

U Operativnom centru, bazi UNPROFOR-a, održavani su redovni brifinzi koje autor pomno opisuje u svojim bilješkama, uključujući i poneki znakovit razgovor prije i nakon samih brifinga. Ti detalji su posebno važni nakon situacija u kojima su se Ancel i njegovi ljudi, u jednoj prilici i on izdvojeno, suočavali sa smrtnom opasnošću zbog direktnog srpskog napada na njih, a ipak je i pri tome izostala reakcija UNPROFOR-a. Formalno su imali odobrenja da uzvrate, ali - bez vatre, što je bio apsurd u situaciji direktnih napada. Time je i cijela misija uništavanja naoružanja iz kojeg su Srbi grantirali Sarajevo dobila karakter nemoguće, zaključuje Ancel.

Njegov tim su činili dobro obučeni i iskusni vojnici sa kojima je kroz školovanje ili misije postao i prijatelj, pa se kroz sve autorove bilješke, komentare, bojazni i reakcije, uvijek proteže briga za onog drugog, od momenata direktne opasnosti po život do potrebe da se sjete koleginog rođendana ili zabrinu za sudbinu koja će ga zadesiti zbog nedvosmisleno iznesenog neslaganja sa odlukom nadređenog. Dobro poznajući karakter Legije stranaca i čast koju će čuvati po cijenu smrti, u Ancelu raste nezadovoljstvo i nerazumijevanje takve politike koja je spremna da žrtvuje vojnike između ostalog zarad - u jednoj situaciji izrečeno čak od visokog oficira, ,vječitog prijateljstva Francuza i Srba“.

Same naredbe su išle po komandnom lancu UN snaga, a Francuska je putem svojih zvaničnika u to vrijeme imala ključnu ulogu u njemu. Vojska nije mogla odlučivati o tome i Ancel Guillaume je u situaciji kad je ispoštovao propise, ali i iskazao i ljudski i vojnički revolt zbog apsurdnog sprečavanja misije, trebalo da bude vraćen kući. No, iskustvo, 18 kovčega poslatih porodicama vojnika, više desetina ranjenih vojnika za šest mjeseci u Sarajevu, i konačna spoznaja janusovog lica francuske politike samo je pojačala visprenost ovog časnog oficira, poraženog obesmišljavanjem cijele misije. Ostao je do kraja mandata, polovine jula 1995. Tako se našao i u prilici da pri preuzimanju naručenih fotografija iz zraka u Centru za zračne operacije vidi snimke sa srebreničkog područja, „masovne egzekucije kojima i sami neposredno asistiraju“, ljude u grupama, tijela žrtava na dnu rovova i Srbe koji se i ne trude sakriti iako znaju da iznad njih nadlijeću avioni radi fotografiranja. „Ne mogu a da ne pomislim na Ruandu“, kaže Ancel u toj pretposljednjoj bilješci, ,gdje smo pustili kriminalce najgore vrste da rade šta hoće..." 
Kroz Ancelova iskustva tokom pripreme i izvršenja zadataka, dopunjena objašnjenjima koja su nekad dobijana u neformalnim razgovorima, čitalac dobija potku ovih sjećanja: misija Ancelovog tima je bila da primijene sporazum neutralizirajući teško naoružanje Srba oko Sarajeva, ali je timu bilo zabranjeno da djeluje i najviše što se postiglo jeste simulacija zračnih napada. Nakon stručne, propisne i uspješne potrage i lociranja teške artiljerije od dobro obučenih i iskusnih vojnika TACPa, uobičajeno bi uslijedilo neutraliziranje motornog ili automatskog naoružanja koje nije pod kontrolom UN-a. Iako je tim započinjao te aktivnosti u potpunosti propisanom procedurom, neposredno pred samo realiziranje zračnih napada, u momentu kad je patrola navedena do mete i kad treba da ispaljuje, zadatak bi bio obustavljen. Autoru su prve takve situacije, a bilo ih je više od stotinu, bile donekle možda objašnjive potrebama koordinacije snaga UN-a, no nadalje je postajalo sve jasnije da je riječ o pravom licu francuske politike i prezentaciji misije onim što ona nije bila. Umjesto da zaštite grad humanitarnom misijom, opsada je produžena nesprečavanjem srpskih napada.

Izuzmemo li namjernu autorovu izmjenu nekih ličnih imena, čitalac sa živim doživljajem ratnog Sarajeva prepoznat će u potpunosti događaje koje ovog puta predočava treća strana u opsadi grada. Nizanje detalja u hronološkom slijedu dešavanja na aerodromu, kreativno je razbijeno detaljima iz privatnog života Guillaumea Ancela. Njegovo snalaženje oko načina da se vidi sa suprugom u danima kad avion Specijalnog predstavnika Gen. Sekretara UN-a za Bosnu i Hercegovinu, Yasushi Akashija biva takođe bombardiran od srpskih snaga, te ubačeni fragmenti života njegove porodice u Francuskoj i jedne djevojčice sa Dobrinje pod granatiranjem, knjizi daju emotivni ton svakodnevice običnog čovjeka.

Ancel nije imao dvojbi oko toga da li je ili nije trebao ili smio pisati o operaciji u Sarajevu nakon izlaska iz vojske. Po njemu, humanitarna misija francuske vojske u Sarajevu nije bila povjerljiva po svom karakteru, nije bila ni to što je trebala da bude, nego historijska laž francuske politike koja je nepravedno radila u korist srpskih snaga. U više navrata je medijski objašnjavao da je demokratsko pravilo da vojska ne može kritizirati političke naredbe, Čak i govoreći o Daytonskom sporazumu, autor citira riječi historičara Tony Judta koji govori da je cilj francuskog insistiranja da bude domaćin ceremonije potpisivanja bio samo da se skrene pažnja sa prethodne nevoljnosti Francuske da djeluje protiv Srba. Prikaz ćemo zaključiti znakovitim riječima jednog drugog historičara, uporedo autora predgovora ove knjige o Sarajevu, Stéphane Audoin-Rouzeaua, da Ancelovo djelo predstavlja diskurs istine kojim nas je obavezao da ju širimo. 